\title{
Systems of Innovation, Multidisciplinarity, and Methodological Pluralism: A Realist Approach to Guide the Future of Information Systems Research and Practice
}

\author{
Arturo Vega ${ }^{1}$ and David Brown ${ }^{2}$ \\ ${ }^{1}$ Canterbury Christ Church University, Canterbury, United Kingdom \\ arturo.vega@canterbury.ac.uk \\ ${ }^{2}$ Lancaster University Management School, Lancaster, United Kingdom \\ d.brown@lancaster.ac.uk
}

\begin{abstract}
Information systems (IS) are complex phenomena. For instance, the diffusion of IS in small and medium enterprises (SMEs) depends on various levels of networked, localized, and changing determinants, such as the ones related to the adopter organizations, decision makers, technologies, complementary innovations, business partners, professional groups, universities, and government policies. This complex view of IS implies the use of different disciplines and methodologies to study the diffusion process. The objective of this empirical research is to demonstrate how the systems of innovation approach (SIA), for addressing the institutional and evolutionary determinants of diffusion, and the philosophical stance of critical realism (CR), for guiding the research process, are compatible and meet the multidisciplinarity and methodological pluralism required to move on the field of complex IS and recommend meaningful actions to practice. To exemplify our arguments, we focus the study on one relevant determinant that affects the diffusion of IS in SMEs, namely government programs.
\end{abstract}

Keywords: Information systems research and practice, systems of innovation approach, critical realism, multidisciplinarity, methodological pluralism, information systems and SME policies.

\section{Introduction}

There has been strong criticism regarding the low impact of the research produced by the IS community. For example, Hirschheim and Klein (2003) argued that mainstream IS research does not address relevant topics and its results are not usable for practitioners. A related debate in the IS research community concerns the core of the IS discipline. Benbasat and Zmud (2003) proposed that the core is the information technology artifact. Alter (2003) went further, suggesting that the core should be the systems in organizations. In general, the acceptance of the existence of a core implies narrowing the IS field to fundamental concepts. Conversely, the position of Myers (2003) is that the IS field is far from ready to define a core. Myers argues that the core has been modified many times given the rapidly changing environment of the field, 
and that a concrete core would not consider research that has proved to be extremely valuable, for example information economics (e.g., Bakos and Kemerer 1992) and IS research on institutions (e.g., King et al. 1994; Robey and Boudreau 1999), industries (e.g., Crowston et al. 2001), and countries (e.g., Ein-Dor et al. 1997; Watson and Myers 2001). We completely agree with Myers' view.

Accordingly, the diffusion of IS in SMEs is a complex process that requires the coordinated activity of numerous participants far beyond the adopter organization (Vega et al. 2008, 2010b), as well as the adoption of complementary innovations by many of these participants (Vega et al. 2010a). A simplified example is an SME that operates in the human resource sector and wants to adopt a transactional website to serve employers and applicants. Clearly, the success of the SME will depend on the adoption of this system by employers and applicants. The SME will also depend on its initial adoption of broadband and the availability of the system in application service provider technology. The owner-manager of the SME might need the assistance of several public programs to accomplish all stages of the adoption process, for instance for the selection of the system, technologies, and providers, for the design of a marketing plan to launch the website, and to get soft funding for the entire process. Moreover, program organizations will depend on external factors that are determined in the policy system in order to deliver proper services to SMEs, such as the evaluation mechanisms and the access to resources determined by the funding bodies at the highest levels of public governance. Noticeably, this hypothetical scenario differs depending on the location of the participants. For example, the providers of broadband could be reluctant to operate in isolated regions. Finally, the scenario should also change over time. For instance, the owner-manager could learn about marketing after taking a course in a university.

However, mainstream IS research has basically focused on the accounting of discrete factors of the organization and micro-environment that directly impact the adoption in the SMEs (e.g., Chitura et al. 2008; Fichman 2004; Jeyaraj et al. 2006; Parker and Castleman 2007; Williams et al. 2009). For example, the characteristics of the SME, the decision maker, the IS, customer power, and competitor initiatives. Fichman $(2004$, p. 315) described this predominance as the "dominant paradigm" and the "economic-rationalistic model." Accordingly, Chitura et al. (2004, p. 1) concluded that "researchers should stop reinventing the list of adoption barriers but instead focus their efforts on how SMEs can overcome these barriers."

Under this context, we argue that the diffusion of IS in SMEs should be researched using the SIA in order to explain the institutional and evolutionary complexity that goes much further than the organization and its micro-environment. Similarly, it would be productive to study the diffusion of IS in SMEs using the deep ontological perspective of $\mathrm{CR}$ to guide every iteration of the research process. As we will demonstrate, the compatibility between the SIA and CR stresses the need of using multiple disciplines and methodologies with the aim of researching complex IS in a comprehensive way and improving the value given to practitioners. In general terms, we postulate an end-to-end research approach to address the practical problems and opportunities of IS phenomena. In our view, mainstream IS research is limited in many cases and represents only the initial stage of a research process.

The SIA has been expressly and properly applied very few times to study the diffusion of IS. For example, Mansell and Wehn (1998) addressed the diffusion of IS 
in developing countries. They called for tailored strategies depending on national or regional technological strengths and development priorities. They gave recommendations mostly concentrating on the supply side. Oyelaran-Oyeyinka and Lal (2006) did a cross-country comparison in the export sector to develop a typology of SMEs based on technological and learning capabilities. They identified systemic determinants and potential interventions for the internationalization and take-up of IS by SMEs. Finally, the work of Vega et al. (2008, 2010a, 2010b) attempts to emphasize the relevance of the SIA in IS diffusion, exemplifying this with case studies of IS adoption by SMEs, explaining a series of systemic barriers affecting the adoptions, and recommending interventions in the system with the aim of improving the coordinated work of its parts and ultimately the diffusion process.

Although slowly increasing, the use of CR in the IS literature is very limited. Radically, Carlsson (2005, p. 97) stated that "CR is almost invisible in the IS field." Similarly, Dobson et al. (2007, p. 138) said that there is a "dearth of practical examples of research in the area." In general terms, we could classify the CR works in IS into three groups. The first are the calls to the IS research community to realize the underlaborer value of CR in IS research (e.g., Carlsson 2004; Dobson 2001; Mingers 2004; Mutch 2002; Smith 2006). Most of these works have been conceptual discussions on how CR can overcome the inconsistencies of the positivist, interpretivist, and postmodernist research practices. The second group is composed of conceptual discussions about the appropriateness of CR to study specific IS topics such as IS evaluation (Carlsson 2003), IS design (Carlsson 2005), organizational use of information (Mutch 1999), IS functions to address operational risks (Rotaru et al. 2009), and information seeking behavior (Wikgren 2005). The third are basic empirical attempts to use CR in order to show its suitability to research particular IS issues, for example the implementation of IS (Dobson et al. 2007), IS investment decisions (Fox 2009), the life cycle of strategic IS plans (Morton 2006), and the perception of users on the impact of IS on practice (Oroviogoicochea and Watson 2009). Most of the explanations and usage of CR in IS has been at the organizational level.

There were also few efforts to connect the SIA and CR from a generic perspective (e.g., Castellacci 2006; Iliev 2005), and not in terms of IS. Basically, the discussion has centered on the critics of CR proponents to the reduction of the reality and the simplistic research approach used in neoclassical economics to study industrial development. There is also recognition of the relevance of heterodox economics as a pillar of the SIA. However, a core conclusion is that there has been a simultaneous coexistence and tension between the diverse philosophical assumptions declared by SIA scholars, which has been caused in large part by a lack of clarity of the SIA concepts. This controversy has proved to be counterproductive for the development of the field. However, CR resolves this divergence and provides a solid grounding to the SIA research practice.

This paper addresses the application of the SIA and CR on complex IS. We focus on one highly relevant determinant of the system of innovation for the diffusion of IS in SMEs, namely government programs (e.g., Berkeley et al. 1996; Cuadrado and Garcia 2004; Gengatharen et al. 2005; Lebre 1995; Simpson and Docherty 2004). Importantly, there is a general concern regarding the quality of the government support to SME innovation (Johnson 2005; Martin and Matlay 2001; Mole 2002; Nugent and Yhee 2002). The topic is even more relevant if we consider that our 
empirical work demonstrated that there is a negative and enduring context affecting programs. This comprehensive research inquires from the micro aspects of IS innovation in SME organizations to the macro structures in the policy system. The paper starts with a revision of the foundations of the SIA and CR. We continue with an explanation of how CR solves some deficiencies in the SIA research practice, as well as the conceptual commonalities between them. We then explicate the aim, theories, research design, and findings of each level of our empirical research process. We conclude by summarizing the correspondence between the IS phenomenon under study and the systemic and realist perspectives, as well as defining a roadmap for the future research of complex IS.

\section{Systems of Innovation Approach}

The SIA (see Freeman 1987; Lundvall 1992; Nelson 1993) was developed under the foundation of innovation research and institutional and evolutionary economics (e.g., Lundvall and Borras 2005). In addition, it is related to general systems theory (e.g., Edquist 2005). The SIA is a conceptual device, which includes "all important economic, social, political, organizational, institutional, and other factors that influence the development, diffusion, and use of innovations"(Edquist 1997, p. 14). From a dynamics perspective, the SIA defines innovation as an open, interactive, and nonlinear learning process (Lundvall 1992), which is affected by the capabilities (e.g., laws, common practices, power distribution, and trust) and accumulated knowledge in communities, business networks, and organizations (Asheim and Isaken 2000). Reciprocally, the capabilities and accumulated knowledge change locally as a result of learning trajectories, which are driven by societal actors (Asheim and Isaken 2000). Thus all this complexity creates uncertainty around innovation activities (e.g., Meyer et al. 2006). Finally, private or public interventions should be based on the detection of visible problems and the subsequent identification of causal explanations at any part of the system, namely system failures (Edquist 2002, 2008). System failures can occur given the inappropriateness or missing of activities, actors, institutions, or linkages (Edquist 2002, 2008). The activities are the factors that influence innovation, the actors are the individuals or organizations that perform the activities, the institutions determine the capabilities to carry out activities, and the linkages are the connections between activities, actors, and institutions.

\section{Critical Realism}

CR (see Archer et al. 2001; Bhaskar 1989; Danermark et al. 2001; Sayer 1992) was developed based on the general philosophy of science called transcendental realism (Bhaskar 1997) and the more specific human science philosophy named critical naturalism (Bhaskar 1998). Basically, CR states that there is a concrete and mindindependent reality that has real consequences on the perceptive and cognitive functions of social actors. It means that $\mathrm{CR}$ is a compromise between the two extreme philosophical positions, namely positivism and interpretivism (e.g., Easterby-Smith et al. 2008). For critical realists, the world operates at multiple levels, and each level has 
the capacity to affect other levels in diverse and localized ways (Archer 1995; Bhaskar 1997). For example, an individual can be affected by the characteristics of the organization in which he or she works, the organization can be affected by its industrial sector, and all of them can be affected by the regional policy system, the national culture, and the global economy. Also, the real world is open and changes relatively fast given human agency in the reproduction and transformation of social structures and causal mechanisms (Archer 1995; Bhaskar 1998). Given this complexity, both the knowledge-creation process and research become on-going and time-dependent activities. Consequently, in order to explain and control the tendencies of events in the social world, we have to understand the underlying processes of often temporal, counteracting, and contingently related structures and mechanisms that give rise to these events. According to Pawson and Tilley(1997), there are mechanisms that cause problems in a social setting and mechanisms that can be applied to block or neutralize the problems.

\section{The SIA Research Practice and CR}

The SIA places the object of study (i.e., innovation processes) at the center of focus (e.g., Edquist 1997, 2005; Lundvall 1992), leaving methodologies and techniques open to the pragmatic criteria of researchers (Iliev 2005). Certainly, we have not identified any substantial philosophical discussion among SIA scholars in order to guide their methodological choices. While the commitment to methodological pluralism is positive, it has a negative connotation if we consider that the conceptual base of the SIA is still evolving and confusion exists about some of its components (e.g., Edquist 2005; Radosevic 1998).

For instance, it is up to the researcher to decide the boundaries of a system, which could be as diverse as the country, the region, the sector, the technology, or a mix of them (e.g., Edquist 1997, 2005). Another example is multiple definitions of institutions, which for some researchers could mean brick-and-mortar organizations such as government departments and industry associations and for others softer aspects such as national culture and social norms (e.g., Edquist 2005; Radosevic 1998). As a result, SIA researchers have been presenting very different, too descriptive, and superficial accounts of the systems, probably based on their personal preferences on specific methodologies and theories, as well as the limitations to access more diverse data.

Whereas the choice of SIA researchers to address different aspects of the systems could be considered specific entry points to the innovation processes under investigation (Hommen and Edquist 2008), excessively superficial descriptions are a serious constraint to properly explain innovation processes (Radosevic 1998) as well as to determine system failures and formulate relevant advice for practitioners. Against this situation, the adoption of the CR paradigm allows the reconciliation of a variety of systems given the identification of the underlying causal mechanisms that generate and integrate them (Iliev 2005). For this reason, the focus of research should be on deeper structures and mechanisms using multiple methodologies more than accounting the visible and discrete factors that directly affect innovation processes.

In fact, CR can act as a disciplining device and underlaborer of SIA research efforts. However, before claiming this, we have to be sure that the SIA and CR are 
compatible in terms of more fundamental and comprehensive concepts. The next section explains this compatibility and reinforces the arguments presented here about the role of CR to address some deficiencies of the SIA's research practice.

\section{Similarities and Gaps}

The pragmatic and ad hoc attempts to define an ontological foundation to the SIA have been divergent. However, we can appreciate that the conceptual base of the SIA strongly supports the view of the adequacy of $\mathrm{CR}$ as a general ontological framework to explain innovation processes. Basically, an innovation process is complex because it depends on a stratified and intricate array of determinants. Adding to this difficulty, an innovation process is dynamic, given the openness of its causal constituents and the transforming effect of human activity. An innovation process is also localized because of the contained character of the factors affecting the process. Finally, there is correspondence between the definitions of system failures and interventions of the SIA (Edquist 2002, 2008) and the problematic and corrective mechanisms of CR (Pawson and Tilley 1997).

SIA researchers have been making restrictive and varying choices to study innovation processes. From the epistemological perspective, there are concepts of the SIA and CR that are compatible. However, there are missing concepts in the SIA framework which can be supplied by CR in order to guide and improve its research practice. We turn next to explain four aspects that support this view.

\subsection{Focus of Study}

Both the SIA and CR are expressly committed to research the underlying generative structures and mechanisms (e.g., system of activities, actors, institutions, and linkages) that determine the surface events (e.g., innovation outcomes). The imperative is to go to deeper levels by searching the processes that provoked the observed evidence. Therefore, the aim of research is to identify the root complexity of the object of study as a means to recommend strategic actions to practitioners in order to improve social conditions.

\subsection{Research Approach}

The SIA and CR need a starting point for analysis. Lawson (1997) calls the partial regularity of an observable event which at first sight indicates the occasional, but lessthan-universal, state of generative processes over a specific time and space, demiregularity. The SIA uses appreciative theorizing (Nelson and Winter 1982) to explain innovation processes through theoretical abstract reasoning. This approach focuses on relevant points of entry to the innovation processes under investigation (Hommen and Edquist 2008, p. 445) with the aim of producing typological theory. This kind of explanations is idiosyncratic but developed in terms of general variables (Christensen 2006). Typological theory enables practitioners to make discriminating diagnoses under emerging situations (George 1979; Hommen and Edquist 2008). However, the SIA does not expressly specified how to become immersed in the different levels of systems in order to explain the underlying determinants or system failures affecting 
innovation processes. In contrast, $\mathrm{CR}$ scholars name retroduction to the movement from the observable events to the buried generative processes (Sayer 1992).

\subsection{Multidisciplinarity}

According to the SIA and CR, reality is driven by networked, stratified, and open systems. Therefore, the social realm is an intricate, interconnected whole. As a consequence, the explanation of innovation processes necessarily requires an understanding of the formation and simultaneous effects of different interacting determinants, which can be constitutive elements of different disciplines. For example, psychology and business studies are relevant at the company level. Microeconomics and network theories explain much sector behavior. Similarly, institutions and political science deal with aspects at higher levels of society.

\subsection{Methodological Pluralism}

Both the SIA and CR focus on objects of study (e.g., innovation processes) instead of a methodology of study. Accordingly, SIA researchers have used diverse methodologies based on a variety of entry points to systems. However, as many individual researchers may have been biased in terms of points of entry and levels of analysis, their studies have used mono-methodologies. CR can contribute to overcoming this undesired research practice. If the metatheoretical stance of CR were the guide for the whole research process, the selection of data collection and analytical methods would be based on a deep ontological perspective. This implies that a study could employ various methods, derived from various ontological assumptions of the parts of the innovation process under investigation.

\section{The Diffusion of IS in SMEs and Public Programs}

This section explains the aim, theories, research design, and findings of each stage of the research process. The research on IS diffusion in SMEs should begin with the detection of the factors that affect the diffusion in a particular context. The context could include a specific IS, companies of a specific size, a sector of the economy, and a particular region-for example, the diffusion of transactional websites for employers and applicants in the small enterprises of the human resource sector in the northeast of England. This could be done using surveys and statistical analysis, as well as employing widely used theories in the IS field such as the diffusion of innovations (Rogers 2003), the technology acceptance model (Davis et al. 1989), or the absorptive capacity (Zahra and George 2002). As a finding of this exercise, we could determine several barriers affecting diffusion, for instance the knowledge to select the system, technologies, and providers, the knowledge to design a marketing plan to launch the website, or the lack of funding. As mentioned, this kind of research represents in many cases the entire research done on the diffusion of IS in SMEs. We argue that this approach is an excellent way to define important demi-regularities or entry points to guide the research, but it must not be the final objective.

Alternatively, the research approach should try to find underlying causes and determine potential initiatives at any part of the system in order to accomplish the 
ultimate objective, namely, the massive and proper diffusion of IS in SMEs. This kind of research approach takes several stages in order to address every level affecting the diffusion process, with each stage guiding the next in a retroductive way. As an illustrative example, we will focus on the public programs that support IS innovation in SMEs. These programs are aimed at overcoming many of the diffusion barriers detected at the beginning of the research process, such as any lack of knowledge in the SMEs. We start with an exploration with the purpose of identifying a deeper and relevant demi-regularity (i.e., the poor assistance to IS initiatives in SMEs). After this, we address the issue of discretion at the program implementation level. Then we develop a typology of program contexts in order to explain the choice of goals of their workers and the potential for success in terms of service quality and evaluative targets. Finally, we exemplify the numerous systemic issues to better explain the underlying structures and mechanisms affecting programs and, consequently, the diffusion of IS in SMEs.

\subsection{Exploration}

The aim of the exploration was to define the specific research topic and questions. At this stage, the research approach was purely inductive and based on three organizations delivering public assistance to IS adoption in SMEs. We conducted unstructured interviews with the program managers and read secondary data about the programs, the policy system around the programs, and a few of their interventions. We appreciated that some contextual aspects could have negatively influenced both programs and SMEs, including the excessive discretion of program workers, poor evaluation mechanisms, scarcity of resources, low demand for program services, and the complex characteristics of the adoptions that were assisted. As most of these aspects are determined in the system, and not within program organizations, we suspect that these conditions are common and enduring. For these reasons, we considered a relevant demi-regularity to the potential poor assistance of this kind of program. This caused the research on IS diffusion in SMEs to go deeper into the system as suggested by the realist approach to program evaluation (e.g., Henry et al. 1998; Kazi 2003; Pawson and Tilley 1997). The consequent research questions were as follows:

- What is the nature of program interventions?

- What are the nature and consequences of program contexts?

- How could program contexts be improved?

\subsection{Nature of Program Interventions}

This stage of the research addressed a long-standing debate in the political science and public administration fields, namely the existence and effect of discretion at policy implementation. On the one hand, we have the view of the defenders of the existence of discretion (e.g., Ellis et al. 1999; Lindblom and Woodhouse 1993; Lipsky 1980; Long 1999; Maynard-Moody and Musheno 2003). Basically, they argue that discretion has its origins in the political decisions at the highest levels of government, the dependency of policy makers and program managers on program worker activity, as well as poorly defined goals, policies, and procedures. In this situation, public policies tend to be made as much by program workers as by policy makers. On the 
other hand, we have the view of the advocates of a shift in power in favor of policy makers and managers over bureaucrats (i.e., the new managerialism stance) (e.g., Clarke and Newman 1997; Howe 1991; Jones 1999; Langan 2000). New managerialism sees a change in the distribution of power as having occurred because of the centralization of strategic political direction and the inclusion of competition in the delivery of services. This demanding structure would have generated a drastic cultural change in terms of supervision and management responsibilities.

We initially used a deductive approach based on the replication of six case studies (Yin 2009) of program assistance and on the pattern matching analytical method (Trochim 1989). In doing so, we discarded soon the reductionist stance because excessive discretion was present in practically all of the cases. For example, instead of delivering high-level knowledge transfer from academics in a computing department to IT SMEs, a program delivered traditional IS services using third-party service providers to a non-IT SME. After that, we went deeper into the context with the purpose of understanding the underlying causes that gave rise to excessive discretion. Our findings are illustrated in Figure 1.

We defined three levels of activity in order to differentiate the macro and micro ambits of contextual influence (Archer 1995). The first level is the political, which is characterized for the decisions of policy makers at the highest levels of governance (e.g., European Union, national government, and regional authorities). The second level is operational. Here, the political ideology defined at the first level is materialized by funding bodies, auditors, program managers, and program workers. The third level is the street level. Program workers exert discretion when implementing innovation policies, which is permitted by the context initially outlined by policy makers and then realized by the actors of level two.

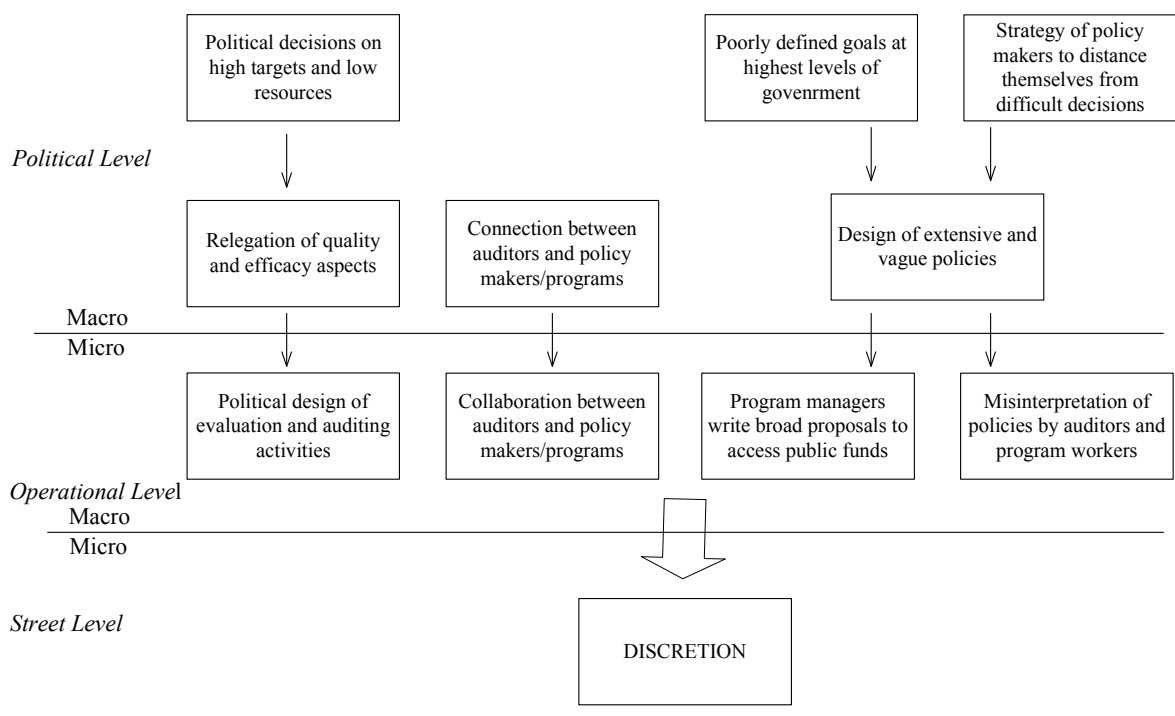

Fig. 1. Contextual Influence on Discretion 
In principle, there is a policy-making imperative of delivering a high quantity of services but being very efficient in the use of resources (e.g., Lewis and Glennester 1996). In this situation, the quality and efficacy of the services would be relegated to a secondary level of relevance. Accordingly, the evaluation and auditing activities were designed to focus on politically relevant issues. For example, a typical indicator was the ratio between funding and SMEs assisted. Another probable cause for discretion is the bottom-up collaboration of auditors with policy makers and programs (e.g., Storey 2006). Basically, funding bodies commissioned the administration of the deployment of funds, including program auditing and control, to organizations with important roles in designing the policies or that were connected to the program organizations; for instance, a university association audited the programs implemented by their members.

Discretion could also be facilitated from top to bottom if the fact that some policy statements were very extensive and vague is taken into account; for example, one long policy had many contradictory statements, including the extremes of "advanced research and development and knowledge transfer" and "websites." This could be a consequence of poorly defined goals at the highest levels of government (e.g., Hasenfeld and English 1974). Policy makers could also use broad policies as a strategy to distance themselves from the consequences of the decisions to balance demand, needs, and resources (e.g., Wells 1997). We found evidence that the broadness in policy definition was exploited by program organizations to formalize discretion when they wrote broad proposals for the selection process to access public funds. Finally, another risk is that auditors and program workers could misinterpret the numerous and unclear phrases of the policies, which could have allowed public interventions to escape even broad policy statements (e.g., Lewis and Glennerster 1996).

Given the excessive discretion identified in the cases, it is important to research in detail the work context and potentially competing priorities of program workers.

\subsection{Nature and Consequences of Program Contexts}

The aim of this level of the research was to explain the macro context and its causal powers (Archer 1995) to the performance of public programs. This stage of the study was based on a collective structure (Stake 2005) of six case studies of program assistance and the abductive analytical method (Bergene 2007; Danermark et al. 2001). The collective structure required the selection of a varied and balanced group of cases that were believed to offer the greatest potential to learn and develop theoretical constructs, for example, cases with program organizations with different operating structures, programs funded by different funding bodies and offering different types of services, as well as assistance to different types of SMEs and IS.

We defined a typological classification of program contexts based on modification and grouping of the Lipsky's (1980) contextual components of public services. These interrelated components include the formal evaluation mechanisms of program assistance, power between programs and SMEs, access to resources by programs in terms of time, knowledge, information, and budget, level of demand for program services, program worker alienation due to any job monotony or limitation, and competition between SME, social, and program goals. This part of the study 
represents an abductive research approach because there was an initial guiding theoretical framework but the development of our theoretical construct was completely dependent on the data.

To begin, we defined two determinants to classify program contexts, namely evaluation result and goal moderator. Evaluation result is determined by the interaction of evaluation and power. A positive influence occurs when the result shows what actually happened in the adoption and assistance processes. A negative influence occurs when the evaluation does not show what happened. For instance, let us consider that the formal evaluation is the quantification of the increase in sales in SMEs after program interventions. Clearly, the increase in sales could be caused by different changes in the SMEs or the market, not necessarily by the program assistance. Additionally, if the SMEs depend on further public assistance to carry out their strategic activities, there would be an imbalance of power in favor of programs. In this case, the evaluation will tend to please programs independently of the quality of the interventions. We argue that the evaluation result influences the focus of program workers on SME, social, or program goals. In our example, there would be a tendency to address program goals (i.e., quantitative targets).

The goal moderator is defined by the situation of the resources, demand, and alienation. A positive influence occurs when none of the contextual components that form the goal moderator present problems. A negative influence occurs when at least one of these components presents problems. For instance, let us consider that because of financial restrictions a program has a short time to service each SME. In this case, the goal moderator will be a negative influence because this problem compromises the delivery capacity of the program. We argue that the goal moderator can determine the extent in which non-focused goals are addressed. Continuing with our example, and assuming a focus on program goals, we can make more concrete inferences regarding program worker behavior, for instance at the selection of SMEs. As the focus is on program goals, the tendency would be to select SMEs with ambitious growth plans in order to reach the quantitative targets. The selection of an SME would not depend on the match between the SME needs and program capacities. However, it would be a matter of coincidence if the program could deliver proper services to some of these SMEs in order to address SME or social goals. The probability of this coincidence will be low because the program has a poor delivery capacity (i.e., a negative goal moderator).

With the combination of the two determinants and their two values, we constructed a classification of four types of program contexts, shown in Table 1. The objective is to explain the choice of goals of program workers and the potential for success of programs in terms of service quality and evaluation targets. We have already exemplified the type chaotic. With regard to the type misleading, the predominance would be for program goals. This is because of the freedom of action allowed by negative evaluation results and because program workers would try to surpass the quantitative targets to have the greatest chance of succeeding in the next public funding rounds. Given the better response situation of this type of programs in terms of the goal moderator, there would be more coincidences among goals in comparison to the type chaotic. The type optimum is the best condition, in which positive evaluation results force program workers to choose social goals and programs are well-prepared to face this challenge. Finally, in the type unsustainable, positive 
evaluation results oblige program workers to opt for social goals. However, given the poor goal moderator, there would be low probabilities to select a great number of SMEs to deliver proper services.

We found that the type chaotic could be the most common program context given the causal effects of the macro context. The reasons for this worrying situation are (1) that most funding bodies set flawed evaluation mechanisms (e.g., the European Regional Development Fund, the Regional Development Agency Fund in England, and the Higher Education Innovation Fund in England), (2) that SMEs tend to depend much on external support given their characteristic lack of resources, (3) that there is a policy-making imperative of providing few resources but setting high targets (e.g., Lewis and Glennester 1996), (4) that there is a low inherent demand for SME innovation services precisely because of the innovative character of these services, and (5) that there is the possibility of alienation of program workers as an indirect consequence of using insufficient resources and poor evaluation mechanisms (Lipsky 1980). In fact, these reasons can explain the deficient outcomes that we found in the IS adoption and assistance processes, as well as confirm the increasing general concern regarding SME policies. These arguments emphasize the relevance of immersing even more in the system in order to research how to improve program contexts.

Table 1. Program Context Types and Behavior

\begin{tabular}{|l|l|l|l|l|l|}
\hline $\begin{array}{c}\text { Evaluation } \\
\text { Result }\end{array}$ & \multicolumn{1}{|c|}{$\begin{array}{c}\text { Goal } \\
\text { Moderator }\end{array}$} & \multicolumn{1}{|c|}{ Type } & \multicolumn{1}{|c|}{ SME Goals } & \multicolumn{1}{|c|}{ Social Goals } & Program Goals \\
\hline Negative & Negative & Chaotic & $\begin{array}{l}\text { If it coincides } \\
\text { with the program } \\
\text { goals, very few } \\
\text { times }\end{array}$ & $\begin{array}{l}\text { If it coincides } \\
\text { with the program } \\
\text { goals, very few } \\
\text { times }\end{array}$ & Tendency \\
\hline Negative & Positive & Misleading & $\begin{array}{l}\text { If it coincides } \\
\text { with the program } \\
\text { goals, sometimes }\end{array}$ & $\begin{array}{l}\text { If it coincides } \\
\text { with the program } \\
\text { goals, sometimes }\end{array}$ & Tendency \\
\hline Positive & Positive & Optimum & $\begin{array}{l}\text { If it coincides } \\
\text { with the social } \\
\text { goals, sometimes }\end{array}$ & Tendency & $\begin{array}{l}\text { If it coincides } \\
\text { with the social } \\
\text { goals, sometimes }\end{array}$ \\
\hline Positive & Negative & Unsustainable & $\begin{array}{l}\text { If it coincides } \\
\text { with the social } \\
\text { goals, very few } \\
\text { times }\end{array}$ & Tendency & $\begin{array}{l}\text { If it coincides } \\
\text { with the social } \\
\text { goals, very few } \\
\text { times }\end{array}$ \\
\hline
\end{tabular}

\subsection{Improvement of Program Contexts}

As pointed out by Archer (1995), agents could continually reproduce or transform the structures that condition their actions. This interaction between structures and agents is called morphogenetic cycle. In the previous section, we explained how program worker activity is affected by its macro context. Accordingly, the aim of this section is to define an initial framework to elaborate a systemic structure that improves program worker conditions. This structure is represented by the system of activities denoted in Table 2. Consequently, the agents in capacity of modifying the structure are the actors identified in the table. 
This stage of the research was another exploration. Doing so, we gathered additional information, for example via semi-structured interviews with regional IS

Table 2. Systemic Initiatives Affecting the Program Context Components

\begin{tabular}{|c|c|c|c|}
\hline $\begin{array}{c}\text { Context } \\
\text { Component }\end{array}$ & $\begin{array}{l}\text { Suggested } \\
\text { Initiative }\end{array}$ & Explanation & Actors \\
\hline Evaluation & $\begin{array}{l}\text { Adoption } \\
\text { and } \\
\text { assistance } \\
\text { process } \\
\text { evaluations }\end{array}$ & $\begin{array}{l}\text { In order to improve the evaluation design, } \\
\text { the methods should include qualitative } \\
\text { approaches and the focus should be on the } \\
\text { outcomes of adoption processes and the } \\
\text { analysis of program actions and inactions }\end{array}$ & Funding bodies \\
\hline Evaluation & $\begin{array}{l}\text { Third-party } \\
\text { evaluators }\end{array}$ & $\begin{array}{l}\text { In order to avoid conflict of interests, the } \\
\text { evaluators should not be connected to the } \\
\text { policy-making teams, the program organi- } \\
\text { zations, or contracted by any of them }\end{array}$ & $\begin{array}{l}\text { Non-departmental } \\
\text { public body, which } \\
\text { could sub-contract } \\
\text { private evaluators }\end{array}$ \\
\hline Power & $\begin{array}{l}\text { SME } \\
\text { empower- } \\
\text { ment }\end{array}$ & $\begin{array}{l}\text { In order to have an influencing presence at } \\
\text { all levels, SME representatives should } \\
\text { improve their involvement in the design, } \\
\text { administration, and evaluation stages of the } \\
\text { policy process }\end{array}$ & SME associations \\
\hline Power & $\begin{array}{l}\text { Marketing } \\
\text { compete- } \\
\text { tion simu- } \\
\text { lation for } \\
\text { programs }\end{array}$ & $\begin{array}{l}\text { In order to avoid the dependency of SMEs } \\
\text { on a single program organization, a group } \\
\text { of program organizations should offer } \\
\text { similar services in the same geographical } \\
\text { area }\end{array}$ & $\begin{array}{l}\text { European and national } \\
\text { entities in charge of } \\
\text { SME policies } \\
\text { Funding bodies and } \\
\text { their regional } \\
\text { delegates }\end{array}$ \\
\hline Resources & $\begin{array}{l}\text { Sector and } \\
\text { functional } \\
\text { area } \\
\text { focused } \\
\text { services }\end{array}$ & $\begin{array}{l}\text { In order to get knowledge and expertise, } \\
\text { program organizations should continually } \\
\text { deliver services to the same sectors and } \\
\text { functional areas }\end{array}$ & $\begin{array}{l}\text { European and national } \\
\text { entities in charge of } \\
\text { SME policies } \\
\text { Funding bodies and } \\
\text { their regional } \\
\text { delegates }\end{array}$ \\
\hline Resources & $\begin{array}{l}\text { Consult- } \\
\text { ancy accre- } \\
\text { ditation }\end{array}$ & $\begin{array}{l}\text { In order to guarantee knowledge and exper- } \\
\text { tise, program organizations could opt to } \\
\text { accredit their practices through rigorous } \\
\text { academic and practical assessments }\end{array}$ & $\begin{array}{l}\text { Professional } \\
\text { associations or } \\
\text { public-private } \\
\text { partnerships }\end{array}$ \\
\hline Demand & $\begin{array}{l}\text { Awareness } \\
\text { campaigns }\end{array}$ & $\begin{array}{l}\text { In order to trigger the agenda-setting in } \\
\text { SMEs, coordinated IS policies should } \\
\text { include campaigns to increase the demand } \\
\text { for IS and program services }\end{array}$ & $\begin{array}{l}\text { Regional entities in } \\
\text { charge of SME } \\
\text { policies }\end{array}$ \\
\hline Demand & $\begin{array}{l}\text { Simplifica- } \\
\text { tion of } \\
\text { contractual } \\
\text { procedures }\end{array}$ & $\begin{array}{l}\text { In order to start program operations on time } \\
\text { and have better chances to reach targets, the } \\
\text { procedures of the policy administrators to } \\
\text { sign contracts should be shortened }\end{array}$ & $\begin{array}{l}\text { Funding bodies and } \\
\text { their regional } \\
\text { delegates }\end{array}$ \\
\hline Alienation & $\begin{array}{l}\text { More com- } \\
\text { prehensive } \\
\text { set of } \\
\text { services }\end{array}$ & $\begin{array}{l}\text { In order to make program workers to } \\
\text { participate more in each SME adoption } \\
\text { process, programs should deliver services } \\
\text { that cover most of the SME's needs }\end{array}$ & $\begin{array}{l}\text { European and national } \\
\text { entities in charge of } \\
\text { SME policies } \\
\text { Funding bodies and } \\
\text { their regional } \\
\text { delegates }\end{array}$ \\
\hline Alienation & $\begin{array}{l}\text { Modifica- } \\
\text { tion and } \\
\text { reduction } \\
\text { of numeri- } \\
\text { cal targets }\end{array}$ & $\begin{array}{l}\text { In order to make program workers partici- } \\
\text { pate more in each SME adoption process, } \\
\text { the targets should be more qualitative and } \\
\text { any numerical indicator should be } \\
\text { reasonably ambitious }\end{array}$ & $\begin{array}{l}\text { European and national } \\
\text { entities in charge of } \\
\text { SME policies } \\
\text { Funding bodies }\end{array}$ \\
\hline
\end{tabular}


policy managers and program managers, as well as by reading diverse academic research, IS policy initiatives of different regions and sectors, and economic policy documents.

It is relevant to state that all of the initiatives presented in Table 2 must be carried out in the system of innovation, and not in the program organizations. For instance, funding bodies are in charge of defining the evaluation design. Another example is the issue of SME empowerment, which should be tackled directly by the SME associations. The systemic initiatives could also be interrelated, which creates even more complexity. For instance, correctly empowered SME groups could influence funding bodies with the aim of changing the evaluation design. Importantly, all of these systemic issues have their own underlying generative structures and mechanisms. This implies that, to study each of them, we would have to consider their particular ontologies, theoretical fields, and research methods.

\section{Conclusions}

We developed a research cycle to show an example of how CR is compatible and supports the SIA research practice to study complex IS. To do so, our early exploration uncovered a relevant demi-regularity, namely the poor program assistance to IS adoption processes in SMEs. After this, we found excessive discretion at the program implementation level. The excessive discretion made relevant the study of the context and priorities in programs. Therefore, we constructed a typological classification of contexts to explain the choice of goals and the potential for success of programs in terms of service quality and evaluative targets. As the type chaotic seems to be the most common context, we decided to explore ways to improve program contexts. Thus we identified a list of interrelated systemic initiatives that could contribute to this end.

In general, the research gives a clear vision about the networked, stratified, and open nature of public programs and, consequently, of the diffusion of IS in SMEs. In fact, the diffusion processes do depend on systemic issues as distant as consultancy accreditation led by professional groups or the decisions on program targets made by funding bodies. In addition, these issues can be complexly interconnected; for example, any focus on sector and area services, initially aimed at improving program resources, could also positively impact the demand for program services.

We used theoretical components that are not utilized in mainstream IS research, specifically the frameworks to explain discretion and program contexts, which come from the political science and public administration fields. In addition, we used a combination of inductive, deductive, and abductive research approaches to carry out the multiple levels of the study, which reflects a deep ontological variety and metatheoretical retroductive reasoning. The multidisciplinarity and methodological pluralism become more diverse if we take into account the detection of the factors of adoption in particular contexts, or initial demi-regularities, which is normally done using mainstream IS theories, surveys, and statistical analysis. More importantly, the study of IS diffusion in SMEs becomes much more complex if we continue researching the systemic issues recommended to improve program contexts. 
This study is an illustration of a meaningful way of how complex IS should be researched. In a particular context, there could be many demi-regularities which must be researched in detail. The lack of knowledge for the planning and implementation of IS, the lack of complementary marketing knowledge to support the company web presence, and the lack of funding to carry out adoption processes are only a few examples of visible factors affecting adoption. Similarly, the underlying causes of the factors can be very diverse, as well as the potential private and public initiatives to address them. This kind of study should take several research iterations and each of them should guide the next.

This research calls for the IS research community to approach IS as a complex social phenomenon, and not as a discrete discipline tied to specific preferences of methodologies and techniques. The most common studies oriented to organizational and micro-environment factors are absolutely relevant as entry points of longer and higher impact research processes, which could contribute significantly more to theory and practice. These research processes, or programs, could be developed forming teams composed of researchers from different disciplines. However, IS researchers should have a leadership role because they are knowledgeable of the organizational processes and micro-environment elements directly affecting the IS phenomenon. For this reason, IS researchers are instrumental in the determination of relevant demiregularities, as well as the initiation, planning, execution, and evaluation of complex IS research efforts.

\section{References}

Alter, S.: Sidestepping the IT Artefact, Scrapping the IS Silo, and Laying Claim to Systems in Organizations. Communications of AIS 12(2), 494-526 (2003)

Archer, M.: Realistic Social Theory: The Morphogenetic Approach. Cambridge University Press, Cambridge (1995)

Archer, M., Bhaskar, R., Collier, A., Lawson, T., Norrie, A. (eds.): Critical Realism: Essential Readings. Routledge, London (2001)

Asheim, B., Isaken, A.: Localized Knowledge, Interactive Learning and Innovation: Between Regional Networks and Global Corporations. In: Taylor, E., Taylor, M. (eds.) The Networked Firm in a Global World: Small Firms in New Environments, pp. 163-198. Ashgate Publishing Group, Aldershot (2000)

Bakos, J., Kemerer, C.: Recent Applications of Economic Theory in Information Technology Research. Decision Support Systems 8(5), 365-386 (1992)

Benbasat, I., Zmud, R.: The Identity Crisis Within the IS Discipline: Defining and Communicating the Discipline's Core Properties. MIS Quarterly 27(2), 183-194 (2003)

Bergene, A.: Towards a Critical Realist Comparative Methodology: Context-Sensitive Theoretical Comparison. J. of Critical Realism 6(1), 5-27 (2007)

Berkeley, N., Clark, D., Ilbery, B.: Regional Variation in Business Use of Information and Communication Technologies and the Implications for Policy: Case Study Evidence from Rural England. Geoforum 27(1), 75-86 (1996)

Bhaskar, R.: Reclaiming Reality: A Critical Introduction to Contemporary Philosophy. Verso, London (1989)

Bhaskar, R.: A Realist Theory of Science, 2nd edn. Verso, London (1997)

Bhaskar, R.: The Possibility of Naturalism: A Philosophical Critique of the Contemporary Human Sciences, 3rd edn. Routledge, London (1998) 
Carlsson, S.: Advancing Information Systems Evaluation (Research): A Critical Realist Approach. Electronic J. of Information Systems 6(2), 11-20 (2003)

Carlsson, S.: Using Critical Realism in IS Research. In: Whitman, E., Woszczynski, B. (eds.) The Handbook of Information Systems Research, pp. 323-338. Idea Group Publishing, Hershey (2004)

Carlsson, S.: Developing Information Systems Design Knowledge: A Critical Realist Perspective. The Electronic J. of Business Research Methodology 3(2), 93-102 (2005)

Castellacci, F.: A Critical Realist Interpretation of Evolutionary Growth Theorizing. Cambridge J. of Economics 30(6), 861-880 (2006)

Chitura, T., Mupemhi, S., Dube, T., Bolongkikit, J.: Barriers to Electronic Commerce Adoption in Small and Medium Enterprises: A Critical Literature Review. J. of Internet Banking \& Commerce 13(2), 1-13 (2008)

Christensen, C.: The Ongoing Process of Building a Theory of Disruption. J. of Product Innovation Management 23(1), 39-55 (2006)

Clarke, J., Newman, J.: The Managerial State. Sage, London (1997)

Crowston, K., Sawyer, S., Wigand, R.: Investigating the Interplay between Structure and Information and Communications Technology in the Real Estate Industry. Information Technology \& People 14(2), 163-183 (2001)

Cuadrado, J., Garcia, A.: ICT Policies for SMEs and Regional Disparities: The Spanish Case. Entrepreneurship and Enterprise Development 16(1), 55-75 (2004)

Danermark, B., Ekstrom, M., Jakobsen, L., Karlsson, J.: Explaining Society: An Introduction to Critical Realism in the Social Sciences. Routledge, London (2001)

Davis, F., Bagozzi, R., Walshaw, P.: User Acceptance of Computer Technology: A Comparison of two Theoretical Models. Management Science 35(8), 982-1003 (1989)

Dobson, P.: The Philosophy of Critical Realism: An Opportunity for Information Systems Research. Information Systems Frontiers 3(2), 199-210 (2001)

Dobson, P., Myles, J., Jackson, P.: Making the Case for Critical Realism: Examining the Implementation of Automated Performance Management Systems. Information Resources Management Journal 20(2), 138-152 (2007)

Easterby-Smith, M., Thorpe, R., Lowe, A.: Management Research: An Introduction, 3rd edn. Sage, London (2008)

Edquist, C.: Systems of Innovation Approaches: Their Emergence and Characteristics. In: Edquist, C. (ed.) Systems of Innovation: Technologies, Institutions and Organizations, pp. 1-35. Pinter, London (1997)

Edquist, C.: Innovation Policy: A Systemic Approach. In: Archibugi, D., Lundvall, B. (eds.) The Globalizing Learning Economy, pp. 219-238. Oxford University Press, Oxford (2002)

Edquist, C.: Systems of Innovation: Perspectives and Challenges. In: Fagerberg, J., Mowery, D., Nelson, R. (eds.) The Oxford Handbook of Innovation, pp. 181-208. Oxford University Press, Oxford (2005)

Edquist, C.: Design of Innovation Policy through Diagnostic Analysis: Identification of Systemic Problems (or Failures). Working paper, Centre for Innovation, Research and Competence in the Learning Economy (CIRCLE), Lund University, Lund, Sweden (2008), http: / / circle-lund. net/UploadedPublications / 200806 Edquist.pdf (accessed November 15, 2009)

Ein-Dor, P., Myers, M., Raman, K.: Information Technology in three Small Developed Countries. J. of Management Information Systems 13(4), 61-89 (1997)

Ellis, K., Davis, A., Rummery, K.: Needs Assessment, Street-Level Bureaucracy and the New Community Care. Social Policy and Administration 33(3), 262-280 (1999) 
Fichman, R.: Going Beyond the Dominant Paradigm for Information Technology Innovation Research: Emerging Concepts and Methods. J. of the Association for Information Systems 5(8), 314-355 (2004)

Fox, S.: Applying Critical Realism to Information and Communication Technologies: A Case Study. Construction Management and Economics 27(5), 465-472 (2009)

Freeman, C.: Technology Policy and Economic Performance: Lessons from Japan. Pinter, London (1987)

Gengatharen, D., Standing, C., Burn, J.: Government Supported Community Portal: Regional E-Marketplaces for SMEs-Evidence to Support a Staged Approach. Electronic Markets 15(4), 405-417 (2005)

George, A.: Case Studies and Theory Development: The Method of Structured, Focused Comparison. In: Lauren, P. (ed.) Diplomacy: New Approaches in History, Theory and Policy, pp. 43-68. The Free Press, New York (1979)

Hasenfeld, Y., English, R. (eds.): Human Service Organizations. University of Michigan Press, Ann Arbor (1974)

Henry, G., Julnes, G., Mark, M. (eds.): Realist Evaluation. Jossey Bass, San Francisco (1988)

Hirschheim, R., Klein, H.: Crisis in the IS Field? A Critical Reflection on the State of the Discipline. J. of the Association for Information Systems 4(5), 237-293 (2003)

Hommen, L., Edquist, C.: Globalization and Innovation Policy. In: Edquist, C., Hommen, L. (eds.) Small Country Innovation Systems: Globalization, Change and Policy in Asia and Europe, pp. 442-484. Edward Elgar Publishing, Cheltenham (2008)

Howe, D.: Knowledge, Power and the Shape of Social Work Practice. In: Davies, M. (ed.) The Sociology of Social Work, pp. 202-220. Routledge, London (1991)

Iliev, I.: Addressing the Methodological Anxieties of the Systems of Innovation Approach: Complementarities with the Critical Realist Project. In: Proceedings of the Danish Research Unit for Industrial Dynamics (DRUID) Academy of Winter 2005 Conference, Aalborg, Denmark (2005),

http: / / www2 . druid.dk/conferences / viewpaper . php? id=2536\&cf=17 (accessed January 15, 2010)

Jeyaraj, A., Rottman, J., Lacity, M.: A Review of the Predictors, Linkages and Biases in IT Innovation Adoption Research. J. of Information Technology 21(1), 1-23 (2006)

Johnson, S.: SME Support Policy: Efficiency, Equity, Ideology or Vote-Seeking? In: Proceedings of the Institute of Small Business and Entrepreneurship (ISBE) Conference, Blackpool, UK (2005)

Jones, C.: Social Work: Regulation and Managerialism. In: Exworthy, M., Halford, S. (eds.) Professionals and the New Managerialism in Public Services, ch. 4. Open University Press, London (1999)

Kasi, M.: Realistic Evaluation in Practice. Sage, London (2003)

King, J., Gurbaxani, V., Kraemer, K., McFarlan, F., Raman, K., Yap, C.: Institutional Factors in Information Technology Innovation. Information Systems Research 5(2), 139-170 (1994)

Langan, M.: Social Services: Managing the Third Way. In: Clarke, J., Gewirtz, S., McLaughlin, E. (eds.) New Managerialism, New Welfare?, pp. 152-168. Sage, London (2000)

Lawson, T.: Economics and Reality. Routledge, London (1997)

Lewis, J., Glennerster, H.: Implementing the New Community Care. Open University Press, New York (1996)

Lindblom, C., Woodhouse, E.: The Policy-Making Process, 3rd edn. Prentice Hall, Englewood Cliffs (1993)

Lipsky, M.: Street-Level Bureaucracy: The Dilemmas of Individuals in Public Service. Russell Sage Foundation, New York (1980) 
Long, N.: The Multiple Optic of Interface Analysis. UNESCO background paper on interface analysis, Wageningen University, Wageningen, Netherlands (1999),

http: / / lanic.utexas.edu/project/etext/llilas/claspo/ workingpapers/multipleoptic.pdf (accessed August 5, 2010)

Lundvall, B.: National Systems of Innovation: Towards a Theory of Innovation and Interactive Learning. Pinter, London (1992)

Lundvall, B., Borras, S.: Science, Technology and Innovation Policy. In: Fagerberg, J., Mowery, D., Nelson, R. (eds.) The Oxford Handbook of Innovation, pp. 599-631. Oxford University Press, Oxford (2005)

Mansell, R., Wehn, U. (eds.): Knowledge Societies: Information Technology for Sustainable Development. Oxford University Press, Oxford. Commissioned by the United Nations Commission on Science and Technology for Development, Geneva, Switzerland (1998), http: / /www. sussex.ac.uk/spru/1-4-9-1-1-2 .html (accessed June 10, 2009)

Martin, L., Matlay, H.: Blanket Approaches to Promoting ICT in Small Firms: Some Lessons from the DTI Ladder Adoption Model in the UK. Internet Research 11(5), 399-410 (2001)

Maynard-Moody, S., Musheno, M.: Cops, Teachers, Counselors: Stories from the Front Lines of Public Service. University of Michigan Press, Ann Arbor (2003)

Meyer, I., Hekkert, M., Faber, J., Smits, R.: Perceived Uncertainties Regarding SocioTechnological Transformations: Towards a Framework. Int. J. Foresight Innovation Policy 2(2), 214-240 (2006)

Mingers, J.: Real-izing Information Systems: Critical Realism as an Underpinning Philosophy for Information Systems. Information and Organization 14(2), 87-103 (2004)

Mole, K.: Business Advisers Impact on SMEs. International Small Business J. 20(2), 139-162 (2002)

Morton, P.: Using Critical Realism to Explain Strategic Information Systems Planning. J. of Information Technology Theory and Application 8(1), 1-20 (2006)

Mutch, A.: Critical Realism, Managers and Information. British J. of Management 10(4), 323-333 (1999)

Mutch, A.: Actors and Networks or Agents and Structures: Towards a Realist View of Information Systems. Organization 9(3), 477-496 (2002)

Myers, M.: The IS Core - VIII: Defining the Core Properties of the IS Disciplines: Not Yet, Not Now. Communications of the AIS 12(38), 580-588 (2003)

Nelson, R. (ed.): National Innovation Systems: A Comparative Study. Oxford University Press, Oxford (1993)

Nelson, R., Winter, S.: An Evolutionary Theory of Economic Change. The Belknap Press, Boston (1982)

Nugent, J., Yhee, S.: Small and Medium Enterprises in Korea: Achievements, Constraints and Policy Issues. Small Business Economics 18(1/3), 85-119 (2002)

Oroviogoicochea, C., Watson, R.: A Quantitative Analysis of the Impact of a Computerized Information System on Nurses' Clinical Practice Using a Realistic Evaluation Framework. International J. of Medical Informatics 78(12), 839-849 (2009)

Oyelaran-Oyeyinka, B., Lal, K.: SMEs and New Technologies: Learning E-Business and Development. Palgrave Macmillan, Basingstoke (2006)

Oztel, H., Martin, S.: Local Partnership for Economic Development: Business Links and the Restructuring of SME Support Networks in the United Kingdom. Economic Development Quarterly 12(3), 266-278 (1998)

Parker, C., Castleman, T.: New Directions for Research on SME E-business: Insights from an Analysis of Journal Articles from 2003 to 2006. J. of Information Systems and Small Business 1(1), 21-40 (2007) 
Pawson, R., Tilley, N.: Realistic Evaluation. Sage, London (1997)

Radosevic, S.: Defining Systems of Innovation: A Methodological Discussion. Technology in Society 20(1), 75-86 (1998)

Robey, D., Boudreau, M.-C.: Accounting for the Contradictory Consequences of Information Technology: Theoretical Directions and Methodological Implications. Information Systems Research 10(2), 167-185 (1999)

Rogers, E.: Diffusion of Innovations, 5th edn. Free Press, New York (2003)

Rotaru, K., Wilkin, C., Ceglowski, A., Churilov, L.: Towards Operational Risk-Aware Information Systems: A Critical Realist Perspective. In: Proceedings of the 17th European Conference on Information Systems, Verona, Italy (2009),

http: / / is2.1se.ac.uk/asp/aspecis/20090140.pdf

(accessed August 15, 2010)

Sayer, A.: Method in Social Science: A Realist Approach, 2nd edn. Routledge, London (1992)

Simpson, M., Docherty, A.: E-commerce Adoption Support and Advice for UK SMEs. J. of Small Business and Enterprise Development 11(3), 315-328 (2004)

Smith, M.: Overcoming Theory-Practice Inconsistencies: Critical Realism and Information Systems Research. Information and Organization 16(3), 191-211 (2006)

Stake, R.: Qualitative Case Studies. In: Denzin, N., Lincoln, Y. (eds.) The SAGE Handbook of Qualitative Research, 3rd edn., pp. 443-466. Sage, Thousand Oaks (2005)

Storey, D.: Evaluating SME Policies and Programmes: Technical and Political Dimensions. In: Cason, K., Yeung, B., Basu, A., Wadeson, N. (eds.) The Oxford Handbook of Entrepreneurship, pp. 248-278. Oxford University Press, Oxford (2006)

Trochim, W.: Outcome Pattern Matching and Programme Theory. Evaluation and Program Planning 12(4), 35-366 (1989)

Vega, A., Chiasson, M., Brown, D.: Extending the Research Agenda on Diffusion: The Case of Public Program Interventions for the Adoption of E-Business Systems in SMEs. J. of Information Technology 23(2), 109-117 (2008)

Vega, A., Chiasson, M., Brown, D.: The Effects of Innovation Process and Programme Contexts on the Implementation of Public Services: The Worrying Case of Enterprise Innovation. In: Proceedings of the 14th International Research Society for Public Management Conference, Berne, Switzerland (2010a),

http: / / www. irspm2010. com/workshops / papers /

G_theeffectsofinnovation.pdf (accessed August 15, 2010)

Vega, A., Chiasson, M., Brown, D.: Setting Up University Support to Small and Medium Enterprise Innovation: Managerial, Policy and Research Implications. In: The Engage HEI (Higher Education Institutions) 2010 Conference, Bradford, UK (2010b)

Watson, R., Myers, M.: IT Industry Success in Small Countries: The Cases of Finland and New Zealand. J. of Global Information Management 9(2), 4-14 (2001)

Wells, J.: Priorities, Street-Level Bureaucracy and the Community Mental Health Team. Health and Social Care in the Community 5(5), 333-342 (1997)

Wikgren, M.: Critical Realism as a Philosophy and Social Theory in Information Science. J. of Documentation 61(1), 1-22 (2005)

Williams, M., Dwivedi, Y., Lal, B., Schwarz, A.: Contemporary Trends and Issues in IT Adoption and Diffusion Research. J. of Information Technology 24(1), 1-10 (2009)

Yin, R.: Case Study Research: Design and Method, 4th edn. Sage, London (2009)

Zahra, S., George, G.: Absorptive Capacity: A Review, Reconceptualization and Extension. Academy of Management Review 27(2), 185-203 (2002) 


\section{About the Authors}

Arturo Vega is a senior lecturer at Canterbury Christ Church University in the Faculty of Business and Management. He has more than 10 years of a varied international experience in the United Kingdom, Spain, Mexico, and Peru in corporations such as Oracle, IBM, Philips, and Red Unicard. Arturo's research is on the development, diffusion and use of innovations in the economic system. Doing so, he uses multiple disciplines and research approaches, including management information systems, critical realism, innovation, entrepreneurship, institutions, public policies, public administration, SMEs, and higher education institutions.

David Brown is Chair of Strategy and Information Systems at Lancaster University Management School. His research interests have two separate but linked strands. First, strategic studies including strategic information systems and e-business, and second the application of these strands internationally, especially in transitional economies. The majority of his work is strongly organizationally based and includes action research and soft systems methodology. He has published widely including three coauthored edited books and over 40 research articles. Current research includes ICT policy, planning and implementation as well as enterprise systems in Chinese SMEs. 